Rapp. Grønlands geol. Unders. 58, 17-32 (1973)

\title{
PRELIMINARY RESULTS OF MAPPING IN THE WESTERN GNEISS AND SCHIST ZONE AROUND VESTFJORD AND INNER GASEFJORD, SOUTH-WEST SCORESBY SUND
}

\author{
W. E. A. Phillips, C. J. Stillman, J. D. Friderichsen and L. Jemelin
}

\section{Introduction}

The western gneiss and schist zone, as referred to by Henriksen \& Higgins (this report), occupies the ground west of a major fault running southwards (west of $28^{\circ}$ W) from Nordvestfjord, down the western side of Rødefjord to Gåsefjord (map 1); the area described here was mapped at a scale of 1:50 000 in the summer of 1972 and extends southwards from ground mapped by GGU in 1970 (Henriksen \& Higgins, 1971). The areas mapped by each of the authors are shown on the key of the geological map (map 1).

\section{Previous investigations and general geology}

A general survey of previous work is given by Henriksen \& Higgins (this report). However, specific reference must be made to Wenk (1961) who, with P. Stern and J. Papageorgakis mapped part of the area and recognised an autochthonous basement with a supracrustal cover. General reviews of the previous GGU mapping to the north of the area have been given by Henriksen \& Higgins (1969, 1970, 1971). Homewood (1973) described an area in the nunatak region to the north, and the structure of the area to the north-east is referred to by Olesen \& Sørensen (1972).

Two supracrustal sequences have been distinguished in the Gåseland area and each rests on an infracrustal basement. The structurally lowest of these sequences is parautochthonous and in places autochthonous to a Precambrian gneissose basement complex which in the main is older than $2290 \mathrm{~m}$. y. (Haller \& Kulp, 1962). As a result of Caledonian thrusting this is overlain by a lower thrust sheet comprising similar but allochthonous basement rocks substantially attenuated and mylonitised by Caledonian tectonism. Above this occurs a higher Caledonian thrust sheet which involves well banded, basement gneisses interleaved with rocks of the second supracrustal sequence which is correlated with the Krummedal supracrustal 
sequence (Henriksen \& Higgins, 1971). A third main thrust sheet consisting of gneisses and migmatitic rocks forms the structurally highest unit.

Three major orogenic events are necessary to explain the complex structural and textural data. The earliest formed an infracrustal gneiss complex which itself may be of a composite nature; a subsequent orogenic event culminated in the deformation, migmatisation and growth of garnet and kyanite in the Krummedal sequence; the youngest event is the Caledonian orogeny. A division into three main orogenic units obtains independent support from the isotopic dating. Haller \& Kulp's (1962) dates of $2290 \mathrm{~m} . \mathrm{y}$. (Rb/Sr on microcline) and $1890 \mathrm{~m}$. y. (K/Ar on biotite) give minimum ages for stages in the formation of the Precambrian gneissose basement complex. In the Flyverfjord infracrustal complex to the north of this area, ages of 2345 m. y. (zircon from foliated granite, Steiger \& Henriksen, 1972) and 2980 m. y. ( $\mathrm{Rb} / \mathrm{Sr}$ whole rock isochron, Rex \& Gledhill, in press) have been obtained. In the Krummedal sequence Larsen (1969) obtained both a Caledonian age of $406 \mathrm{~m}$. y. and a probably mixed age of $616 \mathrm{~m}$. y. from K/Ar determinations upon muscovite and biotite respectively, while Hansen et al. (this report) have obtained a $\mathrm{Rb} / \mathrm{Sr}$ mineral age on biotite of $442 \mathrm{~m}$. $\mathrm{y}$. and a whole rock $\mathrm{Rb} / \mathrm{Sr}$ isochron age of 1194 m. y. for three samples of schist; this last age probably gives a minimum date for the garnet-kyanite metamorphism and the migmatisation of the Krummedal sequence. From granites intruding migmatised Krummedal sequence rocks in the Stauning Alper, Hansen et al. $(1971,1972)$ have obtained $\mathrm{Rb} / \mathrm{Sr}$ mineral dates on biotite, muscovite and potash feldspar ranging from $420-1154 \mathrm{~m}$. y. At least the older of these dates should probably be interpreted as representing pre-Caledonian intrusions or mixed ages reflecting a pre-Caledonian event modified by Caledonian reactivation. A zircon age of $950 \mathrm{~m}$. y. on a foliated augen granite from the migmatite complex in the central fjord zone (Steiger \& Henriksen, 1972) further supports the existence of a pre-Caledonian Proterozoic event.

\section{The infracrustal complexes}

Both autochthonous and allochthonous infracrustal rocks are represented. Correspondence between the gneiss units designated in fig. 2 and those shown in the legend to the accompanying geological map (map 1) is as follows:

Allochthonous: banded to homogeneous gneiss, augen gneiss and chloritic and quartzitic schist

Unit 2

Autochthonous: grey streaky gneiss with discordant amphibolites. Unit 1

\section{Gneisses of unit 1}

These gneisses outcrop in the nunataks south and west of Vestfjord Gletscher, 


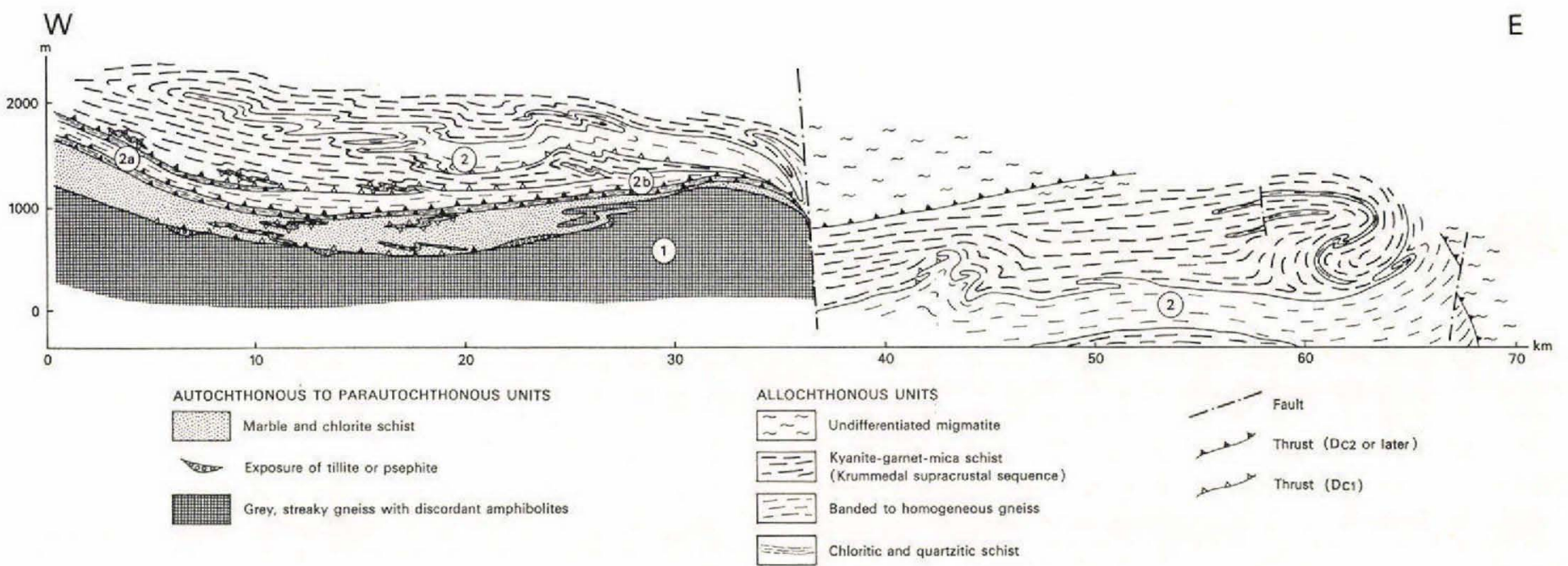

Fig. 2. Sketch profile through the Vestfjord area from the inner nunataks to Rødefjord.

(1) Autochthonous basement gneisses. (2) Allochthonous gneisses. When these are in tectonic contact with the adjacent Krummedal supracrustals they are indicated as (2a) and when the contact is non-tectonic they are indicated as (2b). 
along its margins, in Vindblæsdal around lake 475 and lake 269 and in the area north and west of Paul Stern Land. They are locally unconformably covered by the supracrustal marble sequence, but in many places the gneisses grade upwards with increasing mylonitisation into a series of quartz-sericite schists and chlorite schists which interfinger with the overlying marble sequence.

The gneisses of unit 1 are commonly grey plagioclase-amphibole-biotite gneisses intruded by early basic sheets, which have been subjected to migmatisation with the development of a granitic phase; these events were associated with polyphase metamorphism rising to amphibolite facies, and with the development of intense folding. Subsequently discordant basic dykes were injected and metamorphosed. This entire sequence of events appears to predate the first event in the cover rocks.

The grey gneiss is rather siliceous and banded, and contains some bands very rich in amphiboles. The quartzo-feldspathic layers range from centimetres to decimetres in thickness, have a granular texture and contain plagioclase of composition $\mathrm{An}_{10}$, sometimes with normal zoning from $\mathrm{An}_{20}$ to $\mathrm{An}_{10}$. In the mafic layers green hornblende is associated with biotite, and minor accessory minerals are sphene and epidote.

The migmatitic granitic phase occurs in a series of rock types ranging from discrete bodies of potash-feldspar granite with fresh microcline and saussuritised sodic plagioclase, through net-veined rocks to agmatites and nebulites, the latter corresponding to zones where the gneissic banding is deformed and sometimes almost destroyed.

In a number of places augen granite and augen gneiss sheets cut the grey banded gneiss, the augen gneiss being a foliated variety of the granite. Augened porphyroblasts of feldspar are set in a more biotitic matrix; where porphyroblasts are absent, the rock is homogenous and leucocratic.

\section{Gneisses of unit 2}

This unit outcrops over much of the region and largely comprises banded to homogeneous gneisses with concordant amphibolites.

In the west the unit interfingers with supracrustal rocks. The lower sheet of gneisses, which here is up to $500 \mathrm{~m}$ thick, is extensively mylonitised along the lower and upper margins to form chloritic and quartzitic schists. Towards the centre there are gneisses with abundant concordant amphibolites, which are cut by potashfeldspar granite veins and pre-Caledonian fabrics are seen. The granitic material in places forms net-veined complexes, which elsewhere become agmatitic, and the sequence is cut by later basic intrusives. Despite the more intense flattening the banded gneiss here clearly resembles that of unit 1, though richer in basic rocks. The amphibolites contain up to $30 \%$ of green hornblende, much biotite and quartzo-feldspathic layers are often rich in epidote. Chlorite is present in variable amounts.

In the south and east there is an extensive area of gneisses of unit 2 with a thick- 
ness of more than $1300 \mathrm{~m}$. Lenses and diffuse areas up to kilometre scale of inhomogeneous gneiss rich in ultramafic rocks and discordant amphibolites are interpreted as relics of the original gneiss, which was generally converted to the homogeneous or banded gneiss by cataclasis and recrystallisation. In certain areas these relic gneisses also show migmatisation of the early pods. In the south-eastern part of Vindblæsdal a few thick and rather continuous horizons of amphibolite are found and elsewhere east of Vestfjord Gletscher flattened lenses of amphibolite hundreds of metres long are common. Together with one single but extensive augen gneiss horizon the amphibolites form very useful marker horizons outlining major isoclinal structures in south-east Vindblæsdal.

The lower mylonitic facies of unit 2 is seen west of the north-south trending normal fault crossing the head of Vestfjord, in the nunataks west of Paul Stern Land, in Paul Stern Land, and along the foot of the cliffs which occur on the south-east side of Vestfjord Gletscher and on the northern side of Vindblæsdal. This facies consists of horizontally banded sericitic quartzites, chloritic quartzites and chloritic schists with abundant layers of flinty, dark green blastomylonite. In the Vindblæsdal area there is a considerable development of garnet-muscovite schists and phyllites. Petrographic examination shows the schists to be tectonised gneisses with a strong planar fabric and mineral orientation. They occasionally contain late static porphyroblasts of muscovite and garnet. This lower mylonitic facies, corresponding to the lower part of Wenk's (1961) phyllite-mica-schists series, is also found interleaved with the underlying marble (fig. 2). On both sides of the normal fault, a mylonitic facies is usually developed at the top of the unit 2 and along the margins of wedges of unit 2 interleaved with the overlying Krummedal supracrustal sequence. Further evidence for the tectonic nature of these contacts is shown by the fact that the distinctive amphibolite facies metamorphism of the Krummedal sequence does not affect the gneisses here. On account of this tectonic juxtaposition, the gneisses are designated as $2 \mathrm{a}$.

At Renodde, south of Vestfjord and at one locality on the south side of Paul Stern Land, some gneisses which are lithologically the same as those of $2 \mathrm{a}$ have contacts with the Krummedal which are not tectonic, and they contain garnets which are thought to be developed during prograde metamorphism of the Krumme$\mathrm{dal}$; these are designated as gneisses of unit $2 \mathrm{~b}$.

It is emphasised that this 'Krummedal' amphibolite facies metamorphism apparently did not affect the gneisses of units 1 and $2 \mathrm{a}$ and the autochthonous to parautochthonous cover rocks of unit 1 .

\section{The supracrustal sequences}

The supracrustal rocks have been informally grouped as follows: 
The marble sequence (cover to gneiss unit 1) and the

Krummedal supracrustal sequence (cover to gneiss unit 2).

\section{The marble sequence}

This sequence consists predominantly of a cream-coloured marble which is underlain in a number of places by psephite, quartzite and tillite in descending order.

\section{Tillite and quartzite}

At two localities on the south-western margin of Paul Stern Land psephitic rocks resembling tillites have been found resting unconformably on granite and gneiss of basement unit 1 . The most complete section shows a basal green psephite (up to $4 \mathrm{~m}$ thick) containing clasts of basement lithologies, overlain by laminated purple and green siltstones with 'dropped in' clasts of granite and marble, up to 30 $\mathrm{cm}$ in diameter. The feature of the 'dropped in' clasts is taken as an indication of the tillitic nature of this rock type. The laminated horizon is overlain by up to 26 $\mathrm{m}$ of massive purple psephite with granite clasts up to $40 \mathrm{~cm}$ in diameter, set in quartz sand matrix, and this passes up into at least $8 \mathrm{~m}$ of pure quartzite.

This succession is comparable with the Tillite Group of Ella $\emptyset$ in Kong Oscars Fjord and the Kloftelv Formation, which are conformably overlain by Lower Cambrian fossiliferous rocks (Haller, 1971). It also resembles, in its detailed stratigraphy, the Eocambrian tillite and overlying quartzite found in the Dalradian of the British Isles.

\section{Psephite}

In western Paul Stern Land (western 'T' map 1) there is an angular unconformity (of about $10^{\circ}$ ) between the quartzite of the tillite succession and a quite distinct psephite which is basal to the marble. This psephite consists of a quartz sand with carbonate cement and clasts of marble, granite and gneiss (up to $10 \mathrm{~cm}$ in diameter). Elsewhere along the northern side of Vestfjord Gletscher and on the shores of lake 475 it has been seen in local lenses resting unconformably upon the autochthonous gneiss complex; in these situations it is only a few metres in thickness and is overlain by marble. The tillite succession and this psephite together correspond to the 'basal psephitic series' described by Wenk (1961).

\section{Marble}

The marble is cream-coloured and laminated, with streaks of chlorite and quartz, and horizons of scattered, flattened quartz and quartz-feldspar clasts, up to $1 \mathrm{~cm}$ across. The present thickness varies between 0 and $300 \mathrm{~m}$; however, as the lower boundary is frequently tectonic and the upper boundary always so, and as there are innumerable isoclinal folds and planes of dislocation within the marble, the original thickness is unknown. Within the marble there are many wedge-shaped 
sheets of quartz-sericite schists and chlorite-carbonate schist. The quartz-sericite schists are probably mylonitised gneisses; they predominate near the base of the marble where they have locally been traced gradationally down into basement gneiss and granite. The possibility of a sedimentary origin for part of these schists cannot however be ruled out. The sheets of chlorite-carbonate schist are best developed near the top of the marble, and a gradational passage into overlying amphibolite has been observed in some places in Paul Stern Land, indicating that at least some are the product of mylonitisation of amphibolite. It is also possible that some chlorite-carbonate schist is of sedimentary or pyroclastic origin though no evidence for this has been seen. In south-west Paul Stern Land, where the marble is thickest, the central part is relatively free of these wedge-shaped sheets.

\section{The Krummedal supracrustal sequence}

The lower contact of this sequence is marked by a mylonite in the west, where it forms the cover to gneisses belonging to unit $2 \mathrm{a}$, but in the east the contact sometimes appears to be original and unmoved, and the gneisses below are designated as $2 \mathrm{~b}$. The upper contact, seen only in the high ground immediately north of Vestfjord, is a thrust. The original thickness is unknown but the present exposed maximum thickness is approximately $1400 \mathrm{~m}$; the sequence as a whole is correlated with the Krummedal metasediments to the north. The sequence is relatively uniform, but has a number of variants, both primary and tectonic. The commonest lithology is a kyanite-feldspar-garnet-biotite schist, distinctive for its lack of compositional banding and for the intense augening and lineation of feldspars which are overgrown by later static garnet and kyanite. The schists grade into more gneissic rocks of similar mineralogy in which the augened feldspars are aggregated with quartz into quartzo-feldspathic lenses and bands up to $1 \mathrm{~cm}$ thick. South-west of Renodde there is an upward increase in migmatisation throughout the sequence. Careful examination here has shown that the top of the hill is formed of banded quartz-plagioclase-biotite-garnet migmatitic gneiss which invades earlier amphibolites; both were strongly deformed before injection of white quartz, feldspar, garnet sheets producing local agmatites. Passing down the hill amphibolites, and the conspicuous late neosome, become less abundant and there is a gradation into the normal Krummedal lithologies.

At the base of the sequence, in Vindblesdal and on the southern shore of Vestfjord, there are layers or lenses up to $200 \mathrm{~m}$ thick of amphibolites with impure quartzites; the mafic rocks probably represent metavolcanics. Also, in the nunataks north-west of Rolige Bræ there is a lenticular outcrop of varied metavolcanics which include breccias and agglomerates associated with gabbros and tuffs. Near the base south of Vestfjord and along the north side of Paul Stern Land the lowest $100 \mathrm{~m}$ of the sequence commonly contains isolated boudins and fold mullions of calc-silicates (quartz-feldspar-amphibole-garnet-calcite). Both here and elsewhere in the succession thin $(1 \mathrm{~cm})$ psammitic bands are found in a similar condition. The 
extreme dismemberment of these less ductile bands with the apparently synchronous augening of feldspar porphyroblasts and laminae suggests that incipient migmatisation, growth of porphyroblastic feldspar and deformation were all earlier than the growth of the static garnet and kyanite. Other primary variations include several extensive horizons of well-banded, garnet psammite with calc-silicate bands $1-5 \mathrm{~cm}$ thick, all rich in pyrite. The junction of these horizons with kyanite garnet schist is always sharp.

Fine-grained, muscovite-garnet schist is developed in a 5-100 $\mathrm{m}$ thick tectonic contact zone above the gneisses of unit 2a. In this zone kyanite appears to have been replaced by porphyroblasts of muscovite, and garnet euhedra become progressively augened and broken down as the contact is approached. The facies is clearly the result of cataclasis.

\section{Migmatites and banded gneisses north of Vestfjord}

These migmatitic rocks are seen around peak 1680 north of Vestfjord and just north of Rolige Bræ. They represent the highest structural level and form a major thrust sheet originating probably from the central part of the fjord zone.

The migmatites and banded gneisses north of Vestfjord are lithologically different from the gneisses of units 1 and 2, but seem related to the rocks found in the eastern migmatite zone which is presumed to comprise equivalents of the Krummedal sequence (Henriksen \& Higgins, 1970, 1971).

Three subdivisions are recognised; reddish brown, garnetiferous, banded gneiss with thin marble horizons and local augen granite sheets; grey, amphibolitic, garnetiferous gneisses associated with nebulites; and migmatitic gneisses and migmatites.

The garnetiferous, banded gneisses cover much of the highest ground east of the major north-south normal fault of the ridge between Rolige Bræ and Vestfjord. They consist of alternating grey, quartz-feldspar gneiss horizons 5 to $20 \mathrm{~m}$ thick and brown-weathering, biotite-garnet gneisses. The sequence is several hundred metres thick and in the upper part the gneisses are heavily migmatised, with sheets of granitic neosome and bands of marble. The latter are 20 to $100 \mathrm{~cm}$ thick and form discontinuous sheets. These lithologies also outcrop approximately $5 \mathrm{~km}$ to the north, on the northern side of Rolige Bræ.

The grey, amphibolitic, garnetiferous gneisses outcrop in an anticlinal core exposed above and to the west of the garnetiferous, banded gneisses. They consist essentially of well-banded, grey, garnetiferous gneiss rich in massive amphibolite layers; large lenses of migmatitic granite are developed and in the upper portions the gneiss becomes nebulitic, siliceous and rich in garnet.

The migmatitic gneisses and migmatites occur on the highest ground west of the 
1680 peak. They are leucocratic migmatised gneisses, the paleosome being biotitic and siliceous with small garnets, the neosome being paler and more feldspathic with less garnet and biotite.

\section{Post-tectonic igneous activity}

Two plugs of peridotite have been mapped near Gåsefjord, both cutting through the gneiss. A similar plug is well exposed at Renodde.

Some gabbro bodies are also found close to the Tertiary plateau basalts in Gåsefjord and Hjørnedal; these contain diffuse acid veins near the contacts and a variety of locally derived xenoliths. A preliminary $\mathrm{K} / \mathrm{Ar}$ age determination on one of these bodies gave a Caledonian age of $452 \pm 16 \mathrm{~m}$. y. (O. Larsen, personal communication).

The plateau basalts and a number of NNE-SSW and N-S trending olivine dolerite and basalt dykes are the youngest rocks of the area and are assumed to be of Tertiary age (Watt \& Watt, this report). A few dykes have been seen cutting through the lowest part of the basalts. In some places dykes follow earlier northsouth faults.

\section{Structural and metamorphic history}

On the basis of detailed study of superimposed small-scale structures and metamorphic textures three orogenic events have been recognised in the region. The earliest event is of composite nature and is recognised in the structurally lowest infracrustal gneiss complex (gneiss unit 1), and mainly predates the crystallisation of the potash-feldspar granite dated at $2290 \pm 50 \mathrm{~m}$. y. (Haller \& Kulp, 1962). The gneiss unit 2 was probably formed from the same infracrustal complex as gneiss unit 1 , but has been modified by the later deformations.

This first pre- $2300 \mathrm{~m}$. y. orogenic event was succeeded by a second main orogenic event which produced the gneissification, migmatisation, high grade metamorphism and associated deformation seen in the Krummedal supracrustal sequence, in the eastern part of the gneiss unit 2 rocks and in the thrust migmatitic gneisses.

The third event comprises polyphase folding and thrusting which affects the youngest supracrustal sequence - the marble sequence - and all other rocks. Cataclasis and low grade recrystallisation predominate and the third event is considered to be of Caledonian age. All the large-scale structures in the western part of the area described here are assigned to the Caledonian orogenic event, while to the east early structures and parageneses only suffered local Caledonian reactivation. 
The pre-2300 m. y. orogeny

The structural and metamorphic history of the infracrustal gneiss complex (gneiss unit 1) is best displayed at the north-western end of Vindblæsdal, on the north shore of lake 475 and in the large nunatak about five kilometres west of the lake. The full sequence is as follows:

1. Conversion of 'parent' material to plagioclase-amphibole-biotite gneiss ( $\mathrm{D}_{1}$ foliation and $\mathrm{M}_{1}$ amphibolite facies recrystallisation)

2. Development of small-scale $F_{2}$ isoclines

3. Development of small-scale $F_{3}$ isoclines

4. Intrusion of basic magma to form discordant sheets

5a. Foliation and recrystallisation of basic intrusives under amphibolite facies conditions $\left(\mathrm{D}_{4}\right.$ and $\left.\mathrm{M}_{2}\right)$

5 b. Formation of potash-feldspar migmatite, probably coeval with $5 \mathrm{a}$, but passing locally into discordant massive granite bodies

6. Deformation of migmatites and granite $\left(D_{5}\right)$ and low-grade recrystallisation $\left(\mathrm{M}_{3}\right)$

7. Intrusion of granitic sheets and larger masses

8. Intrusion of discordant basic dykes

9. Gentle folding $\left(\mathrm{D}_{6}\right)$ and medium grade recrystallisation $\left(\mathrm{M}_{4}\right)$ of basic dykes.

All these phases predate the deposition of the marble sequence.

The $2290 \mathrm{~m}$. y. age (op. cit.) may be ascribed to the stages $5 \mathrm{~b}$ or 7 with a possible updating during stage 9 .

The pre-Caledonian orogenic event in the Krummedal supracrustal sequence

The Krummedal supracrustal sequence was affected by a pre-Caledonian event, which can be recognised not only in the Krummedal supracrustal sequence itself, but also in part of the associated infracrustal rocks. In the amphibole-garnet-plagioclase-biotite gneisses of unit $2 b$ at the base of the Krummedal sequence on the southern side of Paul Stern Land there appears to be a comparable sequence of events to those recorded elsewhere in the gneiss complex, with early and late basic intrusives separated by an episode of granitic emplacement; however a new event is represented by the growth of late garnet and kyanite.

Within the Krummedal supracrustal sequence the earliest recognisable event is recrystallisation of varied intensity which produced plagioclase porphyroblasts and bands of quartz-plagioclase neosome $\left(\mathrm{M}_{\mathrm{K}_{1}}\right)$. This was followed by intense flattening and stretching of the feldspars with the development of a quartz-biotite $S$ fabric and the growth of syntectonic garnet $\left(D_{\mathrm{K} 1}\right.$ and $\left.M_{K 2}\right)$. The formation of fold mullions and boudins was probably of this age. The final prograde meta- 
morphic event involved the growth of post-tectonic porphyroblasts of garnet and kyanite $\left(\mathrm{M}_{\mathrm{K} 3}\right)$.

If the $\mathrm{Rb} / \mathrm{Sr}$ whole rock isochron of $1194 \mathrm{~m}$. $\mathrm{y}$. reported by Hansen et al. (this report) reflects the minimum age for the last major metamorphic event in the rocks it must be assumed that the Krummedal supracrustal sequence was influenced by a Proterozoic orogenic event. The $\mathrm{K} / \mathrm{Ar}$ and $\mathrm{Rb} / \mathrm{Sr}$ mineral ages clearly indicate that it was later subjected to a Caledonian reactivation.

\section{The Caledonian orogeny}

The Caledonian orogenic event can be subdivided into three major phases of deformation associated with low-grade metamorphism and intense cataclasis; and it affects both the infracrustal and supracrustal sequences.

The first phase Caledonian deformation $\left(D_{C 1}\right)$ in the autochthon and parautochthon

Near the contact of the marble sequence with the basement all lithologies of the latter become mylonitised, except at unmoved contacts beneath the local unconformities. The mylonitic fabric passes down into the basement for at least $50 \mathrm{~m}$ as an axial-planar flattening fabric to many minor folds with curved hinges. It is also the first deformation fabric in the marble. If it is assumed that the tillites in this area are correlatable with the Eocambrian tillites exposed in central East Greenland (Haller, 1971) the mentioned fabric is of Caledonian age $\left(D_{C 1}\right)$.

The slight angular unconformity observed between the top of the tillite succession and the base of the marble indicates minor warping prior to the deposition of the marble sequence.

On a regional scale this $D_{C 1}$ Caledonian deformation involved the emplacement of innumerable westerly facing thrust sheets and recumbent fold cores of mylonitic infracrustal gneisses into the marble, which also shows gradation from recumbent folding to thrusting; the scale of these structures ranges from tens of metres to several kilometres. The deformation must have involved the interplay of folding, flattening and thrusting. The mylonitic sheets consist of quartz-sericite schist, quartzite and quartz-chlorite schist and all these lithologies are seen in places to grade downward into rock types characteristic of gneiss unit 1.

North of the Vestfjord Gletscher the marble is disposed in a recumbent syncline with a complex $F_{\mathrm{C} 1}$ closure; the hinge line trends NNW-SSE and the fold faces sideways to the south-west or west.

Metamorphism was restricted to syntectonic growth of chlorite, the recrystallisation of calcite to form the platy fabric of the marble, and the flattening of quartz pebbles and lenses.

The first phase Caledonian deformation $D_{C 1}$, in the allochthon

Strong flattening and mylonitisation was produced in all the infracrustal rocks 
and was associated with low-grade recrystallisation (chlorite and biotite grade), resulting in the production of quartz-sericite schists, quartzite and chlorite schists (blastomylonites). At the base of the allochthon these blastomylonites form a series of recumbent folds and thrust sheets protruding down into the top of the underlying marble sequence and facing to the west. In particular, the gneisses of unit 2a in Paul Stern Land show a complete gradation from typical gneiss complex lithologies to blastomylonites, and wedges or recumbent fold cores project upwards and southwards into the overlying Krummedal supracrustal sequence. These banded gneiss and mylonite wedges or fold cores range from 1 to $10 \mathrm{~km}$ in length.

Within the Krummedal supracrustal sequence the $D_{C 1}$ deformation is marked by augen formation of garnet porphyroblasts leading to the eventual mechanical disintegration of garnets, and the replacement of kyanite by muscovite. This retrogression and progressive cataclasis occurs in zones up to $50 \mathrm{~m}$ thick surrounding most gneiss wedges and fold cores; it is further found above the basal tectonic contact with gneisses and mylonites of unit 2 and indicates that these contacts are $\mathrm{D}_{\mathrm{C} 1}$ slide zones.

\section{The second phase Caledonian deformation $\left(D_{C 2}\right)$}

This produced abundant minor folds, cleavage, and large scale recumbent folds and thrusts. The lowest structure observed is a horizontal thrust plane, which has detached many of the mylonitic infracrustal wedges and tectonic sheets within the lower part of the marble sequence from their basement root zones, and which truncated $F_{\mathrm{C} 1}$ folds near the eastern end of Paul Stern Land. Above the basal thrust there is a well-developed horizontal fracture cleavage within the marble which is axial planar to the $D_{C 2}$ refolds of the $D_{C 1}$ mylonitic wedges and tectonic sheets. At this level these second phase folds seldom exceed an amplitude of $50 \mathrm{~m}$.

The top of the marble is marked by a major horizontal thrust plane which separates the upper blastomylonitic wedges and tectonic sheets from their overlying infracrustal root zone. The allochthonous rocks above the thrust never include $D_{C 1}$ infolds of parautochthonous units, which strongly supports the conclusion that the allochthonous units reached their present position after the $D_{C 1}$ deformation. A minimum value of displacement along $D_{\mathrm{C} 2}$ thrust planes towards the south-west, as estimated from the area north of Vestfjord Gletscher, is $35 \mathrm{~km}$.

$A$ higher $D_{\mathrm{C} 2}$ thrust separates the lower mylonitic facies of unit 2 from the more gneissic central facies immediately to the east of Vestfjord Gletscher, where large scale $D_{C 1}$ recumbent folds in the gneisses of unit $2 a$ are truncated by an underlying thrust.

$\mathrm{D}_{\mathrm{C} 2}$ refolds of mylonitic gneiss wedges and recumbent fold cores in the Krummedal supracrustal sequence resemble the mesoscopic folds in the marble, but in the west and north of the area the largest folds are much bigger, reaching an amplitude of at least $10 \mathrm{~km}$. Such large scale folds are not seen south of Vestfjord, 
where $D_{C 2}$ folds are generally less than one kilometre in amplitude. A characteristic feature is the development of asymmetric parasitic folds and a sporadic fracture cleavage. Recrystallisation is generally of low metamorphic grade, associated with cataclasis, but post-tectonic muscovite and locally garnet overprint mylonites. In south-east Vindblæsdal strong flattening of gneiss of unit 2 led to the formation of mica schist horizons where apparently $\mathbf{M}_{\mathrm{C} 2}$ garnet has grown.

\section{The third phase Caledonian deformation $\left(D_{C 3}\right)$}

This is distinguished by folds with near vertical axial planes of varied trend, though predominantly NW-SE. Below the major $D_{\mathrm{C} 2}$ thrust under the Krummedal supracrustals the $D_{C 3}$ disharmonic folds seldom exceed $5 \mathrm{~m}$ in amplitude; however, above this thrust plane there is a sporadic development of folds with amplitudes up to $1.5 \mathrm{~km}$. These folds are also disharmonic and their form can most readily be explained in terms of parallel folding developed above the $D_{C 2}$ thrust which acted as a basal décollement plane.

\section{Regional faulting}

Apart from the low-angle thrusts which have already been discussed, there are major north-south trending faults in the area. An eastern fault or steep thrust separates the 'eastern migmatite zone' from the 'western gneiss and schist zone' as was mentioned in the introduction. A western fault can be traced southwards from Rolige Bræ towards Vindblasdal, and is believed to be the southern extension of the western fault, bordering the graben, shown by Homewood (1973) to extend from Hinks Land to Vestfjord. The downthrow to the east on this fault on the northern shore of Vestfjord is between 1400 and $1800 \mathrm{~m}$, but the throw is much reduced southwards from here and in Vindblæsdal the fault becomes a monoclinal flexture with an amplitude of 700 to $800 \mathrm{~m}$. The eastern fault bordering the graben can be seen north of Rolige Bræ, but it does not reappear to the south from under the ice.

Besides the faults associated with the graben structure other north-south trending normal faults, with displacements of up to several hundred metres have been found, especially in the Vestfjord region.

\section{Conclusions and correlations}

The most important conclusions to be drawn from the mapping of the 'western gneiss and schist zone' during 1972 concern the following:

1. Autochthon and parautochthon stratigraphy

2. Recognition of a pre-Caledonian orogenic event responsible for the pro- 
grade recrystallisation and local migmatisation in the Krummedal supracrustal sequence

3. Characteristics of the Caledonian orogeny in this area.

1. Within the parautochthon and autochthon succession the only undoubted sedimentary rocks are the basal psephites, psammites and tillites, and the marble. The phyllite-mica schist and the chlorite schists included by Wenk (1961) as part of the parautochthonous Groenlandian supracrustal rocks are re-interpreted as mainly comprising mylonitised infracrustal gneisses. Wenk regarded the marble-chlorite schist sequence as the base of the Eleonore Bay Group (Wenk, 1961, fig. 9) but lithological similarity between the tillite succession in this area and the Eocambrian tillites in central East Greenland (Haller, 1971) raises the possibility that both are of the same age. This would imply that the autochthonous marbles correspond to part of the Cambro-Ordovician carbonate succession in central East Greenland.

Steck (1972) describes a tillite in Charcot Land which he compares with either the Eocambrian tillite (Fränkl, 1953) or the supposedly earlier tillite from Gåseland (Wenk, op. cit.). In our view these three tillites may well be of the same (Eocambrian) age.

The proposals would indicate that the Gasseland succession lies on the western margin of the basin in the centre of which (cf. Ella Ø) the Eocambrian tillite slightly disconformably overlies some eleven kilometres of sediments of the Eleonore Bay Group, and that the tillite presumably overlapped this succession southwestwards to lie directly on the foreland in the present inner Scoresby Sund region.

2. The recognition of a pre-Caledonian orogenic event responsible for the prograde metamorphism and deformation of the Krummedal supracrustal sequence is based on the superposition of 'Krummedal structures' on parts of the infracrustal basement, and on later, Caledonian, retrogressive structures and textures on the high-grade assemblages of the Krummedal sequence. The existence of such a preCaledonian event is supported by a Rb/Sr whole rock isochron age of $1194 \mathrm{~m}$. $\mathrm{y}$. on rocks from the Krummedal supracrustal sequence as mentioned by Hansen et al. (this report).

Within the Krummedal supracrustal sequence there is in places an upward increase in pre-Caledonian gneissification and migmatisation ultimately producing rocks which are comparable to those of the eastern migmatite zone. North of Vestfjord, this gradation is replaced by a late Caledonian thrust. In the northern part of the Scoresby Sund region in the nunataks north of Krummedal and in the extreme west of Charcot Land, Henriksen \& Higgins (1969) describe a similar upward increase in migmatisation and also a lateral increase towards the east along Nordvestfjord; they suggest that the migmatites are an integral part of the Central Metamorphic Complex of East Greenland (Haller, 1971). The present work supports the view that this migmatite zone comprises significant pre-Caledonian elements as already suggested by the isotopic age determinations showing mixed pre-Caledo- 
nian and Caledonian ages (1150-400 m. y.; Hansen et al., 1971, 1972; Steiger \& Henriksen, 1972).

Wenk (1961) has discussed the problem of inverted metamorphic gradients in this region. Present mapping shows that the evidence for inversion lies solely within the Krummedal sequence, where there is an upward transition from finegrained, muscovite-garnet schist through kyanite-garnet schist into migmatites. The absence of kyanite and the fine grain size of the lower zone is due to $D_{\mathrm{C1}}$ cataclasis along slide zones where Caledonian muscovite has developed at the expense of kyanite. The upward gradation into migmatite can be explained either by migmatisation initiated from the infracrustal core of a pre-Caledonian nappe (cf. Wenk, 1961; Henriksen \& Higgins, 1969), or by Caledonian structural inversion of a normal pre-Caledonian metamorphic gradient.

3. It should be emphasized again that the metamorphic effects of the Caledonian orogeny in the area described here were entirely low-grade and cataclastic. The situation thus compares very closely with that along the Moine thrust zone in northern Scotland (Soper, 1971).

\section{References}

Fränkl, E. 1953: Die geologische Karte von Nord-Scoresby Land (NE-Grønland). Meddr Grønland 113(6), $56 \mathrm{pp}$.

Haller, J. 1971: Geology of the East Greenland Caledonides. Interscience Publishers, New York, 413 pp.

Haller, J. \& Kulp, J. L. 1962: Absolute age determinations in East Greenland. Meddr Grфnland 171(1), $77 \mathrm{pp}$.

Hansen, B. T. \& Steiger, R. H. 1971: The geochronology of the Scoresby Sund area. Progress report 1: $\mathrm{Rb} / \mathrm{Sr}$ mineral ages. Rapp. Gronlands geol. Unders. 37, 55-57.

Hansen, B. T., Steiger, R. H. \& Henriksen, N. 1972: The geochronology of the Scoresby Sund area. Progress report 2: Rb/Sr mineral ages. Rapp. Grønlands geol. Unders. 48, 105-107.

Henriksen, N. \& Higgins, A. K. 1969: Preliminary results of mapping in the crystalline complex around Nordvestfjord, Scoresby Sund, East Greenland. Rapp. Gronlands geol. Unders. 21, 5-20.

Henriksen, N. \& Higgins, A. K. 1970: Preliminary results of mapping in the crystalline complex of Renland, the southern Stauning Alper and south-west Liverpool Land, Scoresby Sund, East Greenland. Rapp. Grønlands geol. Unders. 30, 5-17.

Henriksen, N. \& Higgins, A. K. 1971: Preliminary results of mapping in the crystalline complex around Rypefjord and R $\varnothing$ defjord, and in northern Milne Land, Scoresby Sund, East Greenland. Rapp. Gronlands geol. Unders. 37, 5-18.

Homewood, P. 1973: Structural and lithological divisions of the western border of the East Greenland Caledonides in the Scoresby Sund region, between $71^{\circ} 00^{\prime}$ and $71^{\circ} 22^{\prime}$ north. Rapp. Gronlands geol. Unders. 57.

Larsen, O. 1969: K/Ar age determinations. Rapp. Grønlands geol. Unders. 19, 62-67.

Olesen, N. $\varnothing$. \& S $\varnothing$ rensen, K. 1972: Caledonian fold- and fabric-elements: a model. Proc. 24th int. geol. Congr., Montreal 3, 533-544. 
Rex, D. C. \& Gledhill, A., in press: Reconnaissance geochronology of the infracrustal rocks of Flyverfjord, Scoresby Sund, East Greenland. Bull. geol. Soc. Denmark.

Soper, N. J. 1971: The earliest Caledonian structures in the Moine thrust belt. Scott. J. Geol. 7, 241-247.

Steck, A. 1971: Kaledonische Metamorphose der praekambrischen Charcot Land Serie, Scoresby Sund, Ost-Grönland. Bull. Grø̈nlands geol. Unders. 97 (also Meddr Grønland 192(3)) $69 \mathrm{pp}$.

Steiger, R. H. \& Henriksen, N. 1972: The geochronology of the Scoresby Sund area. Rapp. Grønlands geol. Unders. 48, 109-114.

Wenk, E. 1961: On the crystalline basement and the basal part of the Pre-Cambrian Eleonore Bay Group in the southwestern part of Scoresby Sund. Meddr Grønland 168(1) 54 pp. 